\title{
THE DEPENDENCE OF MELT VISCOSITY OF POLYMER NANOCOMPOSITES ON TYPE OF CARBON NANOTUBES FRACTAL STRUCTURES
}

\author{
Mikitaev Muslim Abdulahovich \\ Candidate of Chemical Sciences, Senior Researcher, \\ Department of Organic Chemistry and Macromolecular Compounds, \\ Kabardino-Balkarian State University named after H.M. Berbekov \\ I dolbin@mail.ru \\ Chernyshevskogo St., 175, 360004 Nalchik, Russian Federation
}

\section{Kozlov Georgiy Vladimirovich}

Senior Researcher, Department of Organic Chemistry and Macromolecular Compounds, Kabardino-Balkarian State University named after H.M. Berbekov

I_dolbin@mail.ru

Chernyshevskogo St., 175, 360004 Nalchik, Russian Federation

\section{Mikitaev Abdulah Kasbulatovich}

Doctor of Chemical Sciences, Professor,

Department of Organic Chemistry and Macromolecular Compounds,

Kabardino-Balkarian State University named after H.M. Berbekov

I dolbin@mail.ru

Chernyshevskogo St., 175, 360004 Nalchik, Russian Federation

\section{Schiraldi David A.}

$\mathrm{PhD}$ in Chemistry, Macromolecular Science and Engineering Department,

Kent Hale Smith Building, Case Western Reserve University,

David.schiraldi@case.edu

Euclid Avenue, 314, 44106 Cleveland, Ohio, United States of America

\section{Zaikov Gennadiy Efremovich}

Doctor of Chemical Sciences, Professor,

Head of Department of Biological and Chemical Physics of Polymers,

Institute of Biochemical Physics named after N.M. Emanuel, RAS

chembio@sky.chph.ras.ru

Kosygina St., 4, 119334 Moscow, Russian Federation 


\begin{abstract}
As it is known, any real fractal object can be simulated as a bulk or surface fractal. In the first case the structure fractality is extended to the entire volume of the object and in the second one - to its surface. For nanocomposites, the matrix of which makes up polymer poly(ethylene terephthalate)/poly(butylene terephthalate) blend, the fractal dimensions of both structure and surface of ring-like formations of nanofiller (multiwalled CNT) were calculated. It has been found out that in case of their notion as bulk fractals, i.e. matrix polymer penetration in ring-like formations internal regions, the strong enhancement of the nanocomposites melt viscosity is observed and in case of surface fractals this parameter is independent on nanofiller contents.
\end{abstract}

Key words: nanocomposite, blend, carbon nanotubes, melt, viscosity, fractal.

\section{Introduction}

Inorganic nanofillers of different types usage for polymer nanocomposites receiving acquires at present wide spreading [9]. However, the indicated nanomaterials melt properties are not studied enough completely. As a rule, when nanofillers application is considered, then the compromise is achieved between improvement of mechanical properties in solid-phase state, enhancement of melt viscosity at processing, nanofillers dispersion problem and process economic characteristics. Proceeding from this, the relation between nanofiller concentration and geometry and nanocomposites melt properties is an important aspect of polymer nanocomposites study.

It has been shown earlier [8], that nanocomposites polypropylene/carbon nanotubes melt viscosity is not changed practically at nanofiller contents variation within the range of 0.25-3.0 mass. \%. However, in the work [11] the sharp (in 3.5 times) reduction of melt viscosity of nanocomposites on the basis of blend poly(ethylene terephthalate)poly(butylene terephthalate), filled with multiwalled carbon nanotubes (PET-PBT/ MWCT) was found in comparison with the initial matrix polymer blend at MWCT content of 0.45 mass. $\%$ only. Therefore, the present paper purpose is this effect study with the fractal analysis notions use.

\section{Experimental}

The polymers industrial sorts were used: PET was supplied by firm GE Plastics and PBT of mark S6110SF NC010, supplied by firm DuPont TM Crastin. As nanofiller MWCT were used with external diameter ranging between 10 $30 \mathrm{~nm}$ and length of $1.5 \mathrm{mcm}$ of firm Sun Nano production [11].

The PET/PBT blends, having optimal PET content of 20 mass. \%, were blended with MWCT at nanofiller contents of 0.15-0.45\% by weight in melt with usage of twin screw extruder (Bersfort FRG Germany) at temperature of $493 \mathrm{~K}$ and screw rotation speed of $150 \mathrm{rpm}$. After receiving, the extrudate was cooled in water and pelletized. The testing samples were prepared from these pellets using injection molding machine (Windsor, India) at temperature range of 523-558 $\mathrm{K}$ [11].

The uniaxial tension mechanical tests were performed according to ASTM D628 on testing apparate of model AG Rnisd MC of form Shimadzu Autograph at temperature of $296 \mathrm{~K}$ and the cross head speed of $50 \mathrm{~mm} / \mathrm{min}$, that corresponds to the strain rate of $1.67 \times 10^{-2} \mathrm{~s}^{-1}$. Melt flow index (MFI) was measured according to ASTM D1238 [11].

\section{Results and Discussion}

As it was noted above, for nanocomposites PET-PBT/MWCT very strong increase of viscosity (MFI reduction) was observed in comparison with matrix polymer blend [11]. This effect was fixed at very small MWCT volume content $\varphi_{n}$, which can be determined as follows [9]:

$$
\varphi_{n}=\frac{W_{n}}{\rho_{n}}
$$

where $W_{n}$ is nanofiller mass content, $\rho_{n}$ is its density, which for nanoparticles is determined according to the equation [9]:

$$
\rho_{n}=188\left(D_{\mathrm{MWCT}}\right)^{1 / 3}, \mathrm{~kg} / \mathrm{m}^{3},
$$




\section{ТЕХНИКО-ТЕХНОЛОГИЧЕСКИЕ ИННОВАЦИИ}

where $D_{\mathrm{MWCT}}$ is MWCT diameter, which is given in $\mathrm{nm}$.

According to the continuum conception [10] the relation between composites melt viscosity $\eta$, matrix polymer melt viscosity $\eta_{0}$ and $\varphi_{n}$ can be obtained in the form of two simple relationships:

$$
\begin{aligned}
& \frac{\eta}{\eta_{0}}=1+\varphi_{n}, \\
& \frac{\eta}{\eta_{0}}=\frac{2.5 \varphi}{1-\varphi_{n}} .
\end{aligned}
$$

The equations (3) and (4) give the greatest $\eta$ increasing in comparison with $\eta_{0}$ on $0.8-2.0 \%$, that does not correspond to experimentally observed $\eta$ growth in 3.5 times.

The authors [8] proposed the fractal model of polymer nanocomposites melt viscosity change, the main equation of which is the following one:

$$
\eta \sim \eta_{0} l^{2-d_{f}^{\prime}}
$$

where $l$ is flow characteristic linear scale, $d_{f}^{\prime}$ is fractal dimension.

Since carbon nanotubes, possessing anisotropy high degree and low transverse stiffness, are formed in polymer matrix ring-like structures with radius $R_{\mathrm{CNT}}[12 ; 15]$, then this dimensional parameter was accepted as $l$, which can be determined with the aid of the equation [2]:

$$
\varphi_{n}=\frac{\pi L_{\mathrm{MWCT}} r_{\mathrm{MWCT}}^{2}}{\left(2 R_{\mathrm{CNT}}\right)^{3}}
$$

where $L_{\mathrm{MWCT}}$ and $r_{\mathrm{MWCT}}$ are length and radius of carbon nanotubes, respectively.

Since contact polymer matrix-nanofiller is realized through the ring-like structures, then as $d_{f}^{\prime}$ the authors [8] have accepted these structures surface dimension $d_{\text {surf }}$, which is determined according to the following technique. First the specific surface $S_{u}$ was estimated according to the equation [9]:

$$
S_{u}=\frac{3}{\rho_{\mathrm{CNT}} R_{\mathrm{CNT}}},
$$

where $\rho_{\mathrm{CNT}}$ is the density of MWCT rang-like structures, which is accepted equal to $\rho_{n}$.

Then the value $d_{\text {surf }}$ can be determined with the aid of the following formula [9]:

$$
S_{u}=410\left(R_{\mathrm{CNT}}\right)^{d_{s u f f}-d},
$$

where $d$ is dimension of Euclidean space, in which a fractal is considered (it is obvious, that in our case $d=3$ ).

In Fig. 1 the dependence of MFI on MWCT volume contents $\varphi_{n}$ is adduced (the curve 1) for the considered nanocomposites, where the value MFI is determined as follows [5]:

$$
\mathrm{MFI}=\frac{2.33}{\eta}, \mathrm{g} / 10 \mathrm{~min}
$$

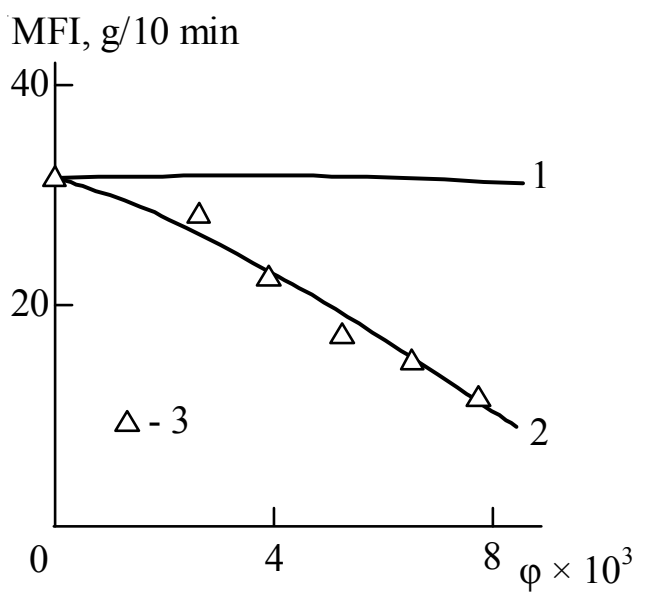

Fig. 1. The dependence of melt flow index MFI on nanofiller volume contents $\varphi_{n}$ for nanocomposites PET-PBT/MWCT:

1,2 - the theoretical calculation according to the relationship (5) for cases of surface (1) and bulk (2) fractals; 3 - experimental data

As it follows from the data of Fig. 1, at the condition $d_{f}^{\prime}=d_{\text {surf }}$ MFI value is practically constant, that does not correspond to the experimental results [11].

As it is known [3], fractals can be divided into two categories: bulk and surface ones. In the first case fractality property is extended to the object volume and in the second one - to its surface only. For the bulk fractals their dimension $d_{f}^{\mathrm{CNT}}$, i.e. dimension of MWCT ring-like structures, is determined with the aid of the relationship [14]: 


$$
R_{\mathrm{CNT}} \sim\left(\frac{4 c_{0} k T}{3 \eta M_{0}}\right)^{1 / d_{f}^{\mathrm{NT}}} t^{1 / d_{f}^{\mathrm{CNT}}},
$$

where $c_{0}$ is nanoparticles initial concentration, which is accepted equal to $\varphi_{n}, k$ is Boltzmann constant, $T$ and $t$ are temperature and duration of processing, respectively, $\eta$ is melt viscosity, $M_{0}$ is mass of separate nanoparticle.

Since the parameters $k, T, t$ and $M_{0}$ are constant, and $\eta \sim \mathrm{MFI}^{-1}$, then the relationship (10) can be simplified as follows:

$$
R_{\mathrm{CNT}}^{d_{\mathrm{CNT}}^{\mathrm{NT}}} \sim \varphi_{n} \times \mathrm{MFI} .
$$

In Fig. 1 the dependence of $\operatorname{MFI}\left(\varphi_{n}\right)$ for the considered nanocomposites is also adduced, which is calculated according to the relationship (5) at the condition $d_{f}^{\prime}=d_{f}^{\mathrm{CNT}}$, i.e. at simulation of MWCT ring-like structures as bulk fractals. In this case the good correspondence of theory and experiment is obtained.

As it is known [6], for bulk fractals penetration of polymer matrix macromolecules into their internal regions is typical. The number of macromolecules $n$, penetrating into these regions, is given by the following relationship [6]:

$$
n \sim R_{\mathrm{CNT}}^{\Delta_{f}},
$$

where $\Delta_{f}$ is the fractal dimension of polymer melt macromolecular coil, determined as follows [1]:

$$
\Delta_{f}=(d-1)(1+v),
$$

where $v$ is Poisson's ratio, estimated according to the mechanical tests results with the aid of the equation [4]:

$$
\frac{\sigma_{Y}}{E}=\frac{1-2 v}{6(1+v)},
$$

where $\sigma_{Y}$ and $E$ are yield stress and elastic modulus, respectively.

In Fig. 2 the dependence of $\operatorname{MFI}(n)$ for the considered nanocomposites is adduced. As one can see, MFI reduction (melt viscosity growth) at $n$ decreasing is observed. At $n \rightarrow 0$ $\mathrm{MFI} \approx 0$ and the change of MWCT ring-like structures type from bulk fractal to surface one occurs.

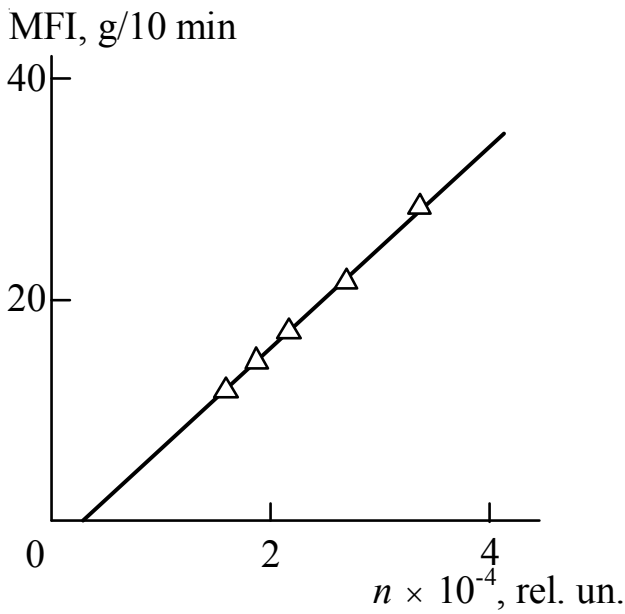

Fig. 2. The dependence of melt flow index MFI on polymer matrix macromolecules number $n$, penetrating in MWCT ring-like structures internal regions, for nanocomposites PET-PBT/MWCT

\section{Conclusions}

Thus, the present work results have shown that the dependence of melt viscosity of nanocomposites polymer/carbon nanotubes on nanofiller contents is defined by fractal structures type, which is formed by the nanofiller. In case of surface fractals very weak dependence of melt viscosity on carbon nanotubes contents is observed and in case of bulk fractals - its essential (in several times) enhancement. The absence of polymer matrix macromolecules penetration in carbon nanotubes ring-like structures internal regions defines the structures transition from bulk fractals to surface ones.

\section{Acknowledgements}

The work is performed within the complex project on creation of hi-tech production with the participation of the Russian higher educational institution, the Contract of Tanneta JSC with the Ministry of Education and Science of the Russian Federation of February 12, 2013 No. 02.G25.31.0008 (Resolution of the Government of the Russian Federation No. 218).

\section{REFERENCES}

1. Balankin A.S. Synergetics of Deformable Body. Moscow, Publishing Ministry of Defence SSSR, 1991. 404 p. (in Russian). 


\section{ТЕХНИКО-ТЕХНОЛОГИЧЕСКИЕ ИННОВАЦИИ}

2. Bridge B.J. Ceramic Matrix Composite Toughening Mechanisms: an Update, in Ceramic Science and Engineering Series. Mater. Sci. Lett., 1989, vol. 8, no. 2, pp. 102-103. $1989.256 \mathrm{p}$.

3. Feder E. Fractals. New York, Plenum Press,

4. Grigoryev E., Vasilyev A., Dolgov K. The Influence of the Arrangement Scheme on Balancing and Mass Dimension Parameters of Engines. Mekhanika, 2006, vol. 61, no. 5, pp. 46-50.

5. Kalinchev E.L., Sakovtseva M.B. Properties and Processing of Thermoplasts. Leningrad, Khimiya Publ., 1983. 288 p.

6. Kozlov G.V., Dolbin I.V., Zaikov G.E. Fractal Physical Chemistry of Polymer Solutions and Melts. Toronto, New Jersey, Apple Academic Press, 2014. $316 \mathrm{p}$.

7. Kozlov G.V., Sanditov D.S. Anharmonic Effects and Physical-Mechanical Properties of Polymers. Novosibirsk, Nauka Publ., 1994. 261 p.

8. Kozlov G.V., Zhirikova Z.M., Aloev V.Z., Zaikov G.E. Structure and Properties of ParticulateFilled Composites: the Fractal Analysis. Polymer Research J., 2012, vol. 6, no. 3, pp. 267-273.
9. Mikitaev A.K., Kozlov G.V., Zaikov G.E. Polymer Nanocomposites: Variety of Structural Forms and Applications. New York, Nova Science Publishers, Inc., 2008. 319 p.

10. Mills N.J. The Rheology of Filled Polymers. J. Appl. Polymer Sci., 1971, vol. 15, no. 11, pp. 27912805.

11. Rajakumar P.R., Nanthini R. A Synthesis of Substituted 4-Aminoquinolines. Int. J. Adv. Chem., 2013, vol. 1, no. 2, pp. 39-42.

12. Schaefer D.W., Justice R.S. Macromolecules, 2007, vol. 40, no. 24, pp. 8501-8517.

13. Vasilyev A. Simulation of Valve Gear Dynamics Using Generalized Dynamic Model. Mekhanika, 2006, vol. 58, no. 2, pp. 37-43.

14. Weitz D.A., Huang J.S., Lin M.Y., Sung J. Dynamics of Diffusion-Limited Kinetic Aggregation. Phys. Rev. Lett., 1984, vol. 53, no. 17, pp. 1657-1660.

15. Yanovskiy Yu.G., Kozlov G.V., Zhirikova Z.M., Aloev V.Z., Karnet Yu.N. Karnet Special features of the structure of carbon nanotubes in polymer composite media. Int. J. Nanomechanics Sci. Techn., 2012, vol. 3, no. 2, pp. 99-124.

\section{ЗАВИСИМОСТЬ ВЯЗКОСТИ РАСПЛАВА ПОЛИМЕРНЫХ НАНОКОМПОЗИТОВ ОТ ТИПА УГЛЕРОДНЫХ НАНОТРУБОК И ФРАКТАЛЬНЫХ СТРУКТУР}

\section{Микитаев Муслим Абдулахович}

Кандидат химических наук, старший научный сотрудник кафедры органической химии и высокомолекулярных соединений, Кабардино-Балкарский государственный университет им. Бербекова I_dolbin@mail.ru ул. Чернышевского, 175, 360004 г. Нальчик, Российская Федерация

\section{Козлов Георгий Владимирович}

Старший научный сотрудник кафедры органической химии и высокомолекулярных соединений, Кабардино-Балкарский государственный университет им. Бербекова

I_dolbin@mail.ru

ул. Чернышевского, 175, 360004 г. Нальчик, Российская Федерация

\section{Микитаев Абдулах Касбулатович}

Доктор химических наук,

профессор кафедры органической химии и высокомолекулярных соединений,

Кабардино-Балкарский государственный университет им. Бербекова

I_dolbin@mail.ru

ул. Чернышевского, 175, 360004 г. Нальчик, Российская Федерация 


\section{ТЕХНИКО-ТЕХНОЛОГИЧЕСКИЕ ИННОВАЦИИ}

Сширалди Дэвид А.

$\mathrm{PhD}$ (химия), отдел высокомолекулярных соединений, Кент Хейл Смит здание, Западный резервный университет Кейза David.schiraldi@case.edu просп. Евклида, 314, 44106 г. Кливленд, Огайо, США

\section{Заиков Геннадий Ефремович}

Доктор химических наук, профессор, заведующий отделом биологической и химической физики полимеров, Институт биохимической физики им. Н.М. Эмануэля РАН chembio@sky.chph.ras.ru ул. Косыгина, 4,119334 г. Москва, Российская Федерация

Аннотация. Как известно, любой реальный фрактальный объект может моделироваться объемной или поверхностной фрактальной размерностью. В первом случае фрактальная структура распространяется на весь объем объекта, а во втором - наблюдается только на ее поверхности. Для нанокомпозитов, матрицу которых составляет полимерная смесь поли(этилен терефталата)/поли(бутилен терефталата), были рассчитаны фрактальные размерности структуры и поверхности кольцеобразных образований нанотрубок (многостенных углеродных нанотрубок).

Ключевые слова: нанокомпозит, смесь, углеродные нанотрубки, расплав, вязкость, фрактал. 